\title{
Understanding factors and barriers to alternative media development in emerging economies: Learning from the Check Global project by Jerome Turner and Dima Saber
}

\begin{abstract}
Check Global is a journalism and digital literacy development project (2019-2021) supporting countries and regions affected by conflict or state controls. In such contexts, expectations are set high for alternative journalism to accurately counter mainstream media narratives, controlled as they often are by the state; this article presents factors to be taken into consideration as a starting point for better understanding the challenges involved in developing journalism, e.g., through funded training initiatives. The article draws on interviews with prominent alternative and independent media outlets (some of them Check Global partners) from India, Latin America, Egypt and Lebanon, who therefore have operational experience of these issues. By viewing digital and social media through an anti-determinist lens, we challenge assumptions - especially prevalent following the 2011 Arab uprisings - that 'open access' and social media platforms can easily provide solutions to media plurality concerns. We explore factors such as the role of technology in alternative media, but also the main barriers faced by alternative media projects and outlets. This article therefore opens up a more honest discussion about the nature of alternative media projects in such contexts, and the ways in which digital literacy projects such as Check Global could support them.
\end{abstract}

\section{Contents}

$\underline{\text { Introduction }}$

Discussion

Conclusion

\section{Introduction}

Digital technologies play a significant role in the development of alternative media and their news sources - where alternative media is defined by its offer of differing approaches, subject areas and voices to those of mainstream media outlets (Atton, 2002). The 2011 Arab uprisings, alongside movements such as \#metoo and \#Occupy in the U.S., and the waves of protests from Brazil to China, have led to a growing consensus among scholars that technological advancements have contributed to enhancing civic engagement and participation around the world (El-Nawawy and Khamis, 2014). Twenty-first century socio-technological transformations have flattened informational hierarchies and altered power structures within our societies (Mourtada and Salem, 2014), in what Mattoni and Treré [1] call a "dance" of media practices and mediation evolving from a comparatively linear production/consumption model. With enhanced skills and improved access to new media tools, online movements have informed 
public opinion in ways that have shaped policy agendas, discourses, government policy and law (Bessant, 2014). In its alignment with or appropriation of sources from such movements, we must also recognise that journalism can also be considered a form of activism (Russell, 2016), in the respect that it stands in opposition or fills the gaps left empty by many mainstream media narratives - as we will discuss in this article.

However, the need to enhance media literacy skills and journalism practices within this picture is nonetheless clear. In this article we push back against any sense that technology in and of itself can 'fix' authoritarian regimes or problems in news media by simply opening access for audiences and producers, in agreement with various scholars (Hirst, 2012; Post and Crone, 2015; Warf, 2011); technology's value is in enabling effective use, but requires training and guidance for best results. One way to achieve this is through development projects such as Check Global [2] (led by technology organisation Meedan and their network of partners across 24 countries in the North Africa Western Asia region and across the Global South), which forms the starting point for much of the discussion in this paper. Check Global:

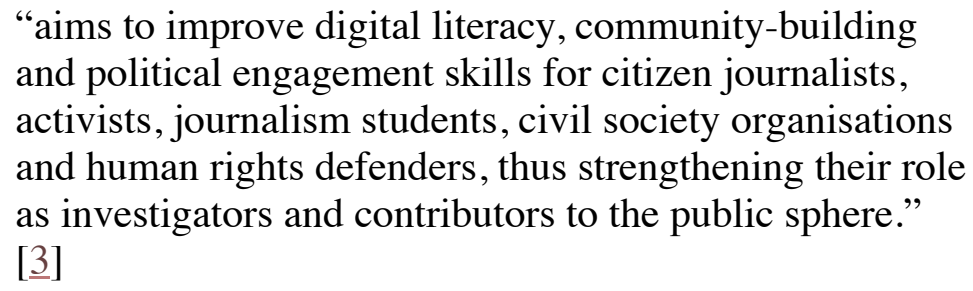

The project approached this through five key areas: training, networks, research, technology and data development. Meedan's earlier work (spanning 2013-2018) focused on the North AfricaWest Asia region (hereafter NAWA). In 2019, and in response to the rising threat of misinformation and discourses around 'fake news', Check Global (2019-2021) was awarded funding by the Swedish International Development Agency (Styrelsen för Internationellt Utvecklingssamarbete, Sida) to expand the team's work to ten countries in East Africa, Southeast Asia and Latin America.

The authors of this article are part of the research and evaluation team who worked on the Check project since conception and through to the Check Global phase. With this in mind, we do consider our own positions, and aspects likely to impact on our interpretation of the Check work and our interviews (England, 1994); one author is from Beirut, and therefore draws on a deep understanding of many of the social, political and cultural issues inherent in NAWA countries. Our reflection in this article also benefits from the additional critical distance brought by the coauthor working from the U.K.

In this article we start by drawing on literature relating to the NAWA regional context, critiquing the technological determinism which emerged in the aftermaths of the 2011 uprisings (the theory that technology 'determines' the development of social and cultural values, as opposed to recognising the agency of technology users). However, we also account for the numerous other barriers to the development of alternative media models, which are becoming increasingly identifiable within global contexts. We draw from Check project activity from October 2014 through to December 2018, and further reports of the Check Global work, 2019-ongoing. These reports include critical reflections on barriers and issues we have encountered during delivery, and narrative reports coming directly from our partners, so their perspectives are therefore included in our reflection here. In 2020 we also interviewed four partners from across the Global South, and Tom Trewinnard, formerly Director of Programs at Meedan. This article therefore identifies some of these key issues faced by alternative and independent media organisations and articulates the ways in which development projects have the potential to address and help overcome them.

\section{The post-2011 NAWA region - A case for developing global alternative journalism in emerging economies}


Starting with protests in Tunisia and continuing throughout other Arab countries, it was hoped that the 2011 uprisings would lead to political reform across the NAWA region. In Tunisia, the social movement led to former President Zein El Abidine Ben Ali fleeing to Saudi Arabia. But it took until the 2019 elections for us to see, what has been described in the media as, "the only democracy to emerge from the 2011 Arab spring" [4]. In 2012, after years of protest and violence, Yemeni President Ali Abdullah Saleh also stepped down, followed by successor Abd al-Rab Mansur al-Hadi. However, power struggles and military interventions resulted in a humanitarian disaster in Yemen (Gallardo, et al., 2016). A similar picture of protest followed by unrest played out in Libya. But it is perhaps in Syria that the impact of conflict was most globally witnessed, in the forced migration of refugees across the NAWA region and into Europe. The war in Syria has resulted in over half a million deaths March 2011-September 2018, with 12 million additional people displaced, according to the Syrian Observatory For Human Rights (2018). In summary, while results of such uprisings have varied across states, scholars (Bennis, et al., 2018; Robbins, 2015) are still tracking human rights violations and violence within these countries, and problems faced by those who seek refuge abroad. In Egypt, the human rights situation was particularly aggravated, as evidenced in the government's crackdowns on journalists, activists and freedom fighters (Human Rights Watch, 2019), and scholars such as Elmasry, et al. (2014) were unable to track any significant improvement in journalistic standards since 2011. As of 2020, the Al-Sisi government continued to repress dissident voices through arrests and prosecutions, while several laws were issued to further restrict freedom of speech and access to information.

It is clear then, that NAWA countries have not yet witnessed the democratic shift hoped for following the 2011 uprisings (Robbins, 2015). Harb's (2019) interviews with Egyptian and Lebanese journalists exposed their concerns regarding safety and job security. Al-Shami [ $\underline{5}]$ similarly identified challenges to investigative journalism across the wider region. Even during the aforementioned 'democratic' Tunisian elections of 2019, scholars identified concerns about the extent to which disinformation and hate speech online could be effectively monitored (Elswah and Howard, 2020). However, barriers to the development of alternative media are not specific to the NAWA region. Whilst the issues may be nuanced in different ways, media in emerging economies of the Global South also need support. This has led to the Check Global project expansion, and our decision here to conduct semi-structured interviews in July 2020 via video call, with four prominent activist/alternative media organisations operating in various contexts, and Tom Trewinnard, formerly of Meedan. Our interviewees were selected on the basis that they represent and can give testimony to the operational concerns of leading alternative media organisations, but also because they have a working overview of each of the countries or regions they are located in. In our review of the situation in the NAWA region above, we have presented this as highlighting many of the issues now also faced by organisations and journalists in other emerging economies of the Global South, such as the Asia-Pacific (APAC) and Latin American regions where Check Global operates. While we recognise their contexts are different to the NAWA region, we have learned through our involvement in the Check project for the last 10 years that the challenges they face are very similar, and wanted to identify exactly how they're addressing them through our interviews. Most of these organisations have been engaged in the Check Global project in one way or another:

- Lara Bitar, Lebanon. Independent media worker \& organizer. Founding editor of journalist-run publication The Public Source [6]

- Disha Mullick, India. CEO of Chambal Media and Khabar Lahariya, India's first digital rural news network, run entirely by women [7].

- Nora Younis, Egypt. Editor-in-chief and founder of Al Manassa, Egyptian alternative media platform []].

- Mariana Santos, CEO and founder, and Belén Arce Terceros, Director of Communication and Editorial, at Chicas Poderosas. The organisation leads in "inspiring and fostering the development of women in the media" [9], and operates in 17 countries in Latin America, and in the United States, Spain and Portugal [10]. 
As many of these regions and countries are developing or in phases of constitutional transition, and given the threat of misinformation to democracy and human rights, citizens need evidencebased media to make informed choices and hold their governments to account (Coulson, 2013). All our interviewees agree that this is at the heart of their work today; that it has become vital for journalists, media activists and transparency advocates to understand and practice evidencebased journalism, to act as efficient voices of dissent. We recognise in this article the difference between definitions of: "independent journalism" (Bennett, 2014), whereby organisations strive for independence in their funding, free from state controls, in order to carry out quality journalism that may nonetheless have much in common with mainstream media, and "alternative media", which Atton (2002) frames as more directly activist and oppositional to mainstream media. To illustrate this point, all four organisations listed above can be considered independent, but Disha resists the label of Khabar Lahariya as 'alternative' in their output, and all that implies. Over the remainder of this article, we therefore explore how alternativity is expressed through action, and independence through approaches to funding challenges (using both terms as appropriate); how digital technologies are used towards the goal of developing their initiatives and the barriers to such efforts; and finally close by suggesting how organisations and/or funders might approach such challenges.

\section{Discussion}

One of the main issues this article is concerned with is an updated understanding of the role of alternative media, and those ideals to which organisations aspire. Given the advent of technologies, and our concerns about any deterministic view that they improve journalism by default (especially in the context of post-2011 citizen uprisings), we first wanted to establish with our interviewees whether they felt journalism ideals had changed. This then allows us to explore the barriers to achieving these ideals, and how they might be managed.

Our interviewees considered that traditional journalism ideals still applied in their everyday practice, perhaps especially in their challenging contexts. Disha Mullick suggested journalism has a democratic responsibility (see also McNair, 2009) to "bring the facts into the public domain", especially given the Indian context of feudal hierarchies which are still ingrained in gender, cost, ethnicity, and often laced with violence. Mariana Santos similarly suggested journalism should "inform society and the population with trustworthy information and a very broad perspective but not a biased point of view," also noting that holding power to account is necessary in a democracy, as per Mulgans view [11]. But she also cited inclusivity as important, supported by her colleague Belén Arce Terceros, who suggests that awareness raising in underrepresented populations is key for any agenda to change public policy.

Lara Bitar told us that, in Lebanon, oppressive tactics towards activists have led to 80 defamation and libel suits over the last six months, 20 of those being aimed at journalists (at time of writing, 8 September 20). Rather than putting her off, she saw it as journalism's duty to resist such tactics as used by the interior ministry, especially given that she felt they were likely to further escalate:

\footnotetext{
"A couple of days ago a couple of television crews were filming on Hamra Street, and the military accosted them and said they're not allowed to film and talk to people there without a permit, saying it's always been the case that you need a permit to film [...] I think as journalists, we have an obligation to resist these types of measures that they're imposing on us. And the only way we can refuse is if we're organized." (Lara Bitar)
}

These demonstrate, therefore, some of the values that alternative media aspire to, and often successfully manage to uphold. Such alternative journalism can be framed as activism (Russell, 2016), in the respect that it actively stands in opposition to mainstream media and/or the 
authorities who control mainstream media, but they only do so by their addressing concerns of media plurality, transparency and accuracy, which should be the default position of news media anyway. Where scholars such as Ataman and Çoban (2018) recognise the "offensive tactics" [12] of some alternative media in "news-making that criticises the authoritarian surveillance state", this article demonstrates perhaps even more strongly, the defensive activist tactics that many organisations must also deploy for their survival, related to "safety of journalists, their sources and data". Increasingly, digital media and tools become part of the means to achieve that, as we'll hear next.

\section{The significance of digital technologies in developing journalism}

One of the key transformative factors in the developing face of alternative journalism is the use of digital media. Given the pressures that outlets in Egypt are under in their operations, it is hardly surprising that Al Manassa's survival as an organisation is so closely correlated to their use of technology, e.g., developing an app rather than reliance on their Web sites, which are consistently closed down.

Many Check partner organisations work entirely online and have always done so, but exploring Khabar Lahariyas transition from newspaper to online hyperlocal channel does well to illustrate news media's journey from off-line to online practice. The organisation originally ran one edition of a newspaper in India, before expanding to a multi-edition chain of rural newspapers. At the same time as this scaling up, and as it became harder to fund the newspaper output, Mullick recognised that "the national and global context of media was shifting towards digital". Over the past seven years their hyperlocal online video channel has gathered 500,000 YouTube subscribers, producing over 8,400 videos. Their prior newspaper model was to train women in their rural communities, reporting on issues important to them. They were trained and enabled to be independent in as many of the journalism and production skills as possible, and in such training narratives, the case is made that training, guidance and learning from the everyday practice of others is key to drawing out the promise of digital media - simply 'being there' is not enough. In the transition to online video production, the same communities were similarly trained, but here, Mullick noted the women's significantly increased confidence working with digital video, and also the speed with which they took up these new skills. Starting with a team that was "only 50 percent confident" using technology such as smartphones and the Internet, 20 women were trained over a period of six or eight months, on storyboarding, shooting and sending on video stories to the Delhi offices for editing and online distribution. This all ultimately resulted in Khabar Lahariya's prior print readership of 80,000 being dwarfed by their five-seven million viewers on YouTube every month, enabled by wider smartphone use - an audience that Mullick says was "beyond the scope of [her] imagination". Mullick estimates that the newspapers were being bought and read by the man of a household and reached only two percent of women in these areas, compared to reaching 10-20 percent of women since they made the switch to digital. In this respect then, the digital medium and platform more immediately allows their platform to challenge traditional mainstream media models in India.

The Public Source described operating within extremely challenging circumstances, struggling with power cuts, an impending Internet shutdown and an unprecedented financial crisis in Lebanon, which clearly affected their ability to sustain their organisation. Beyond their site and platform's use to reach audiences with new journalism, it is also worth noting how The Public Source used digital tools to innovate in other ways, for example in trying to develop use of a whistleblowing platform:

"Some of the people that we have talked to are having a hard time understanding how one could potentially leak information or documents anonymously, so we have a huge role to play in, and - I don't want to use the word educating - but in relaying information on how technology can be used to advance our mission." (Lara Bitar) 
Such narratives expose the struggle of technologically savvy journalists trying to meet their audiences at the same level; journalism isn't just about the act of media production, but also digital literacy and the organisation and management of it too. The digitally literate Chicas Poderosas core team use file sharing and collaborative working tools such as Slack. These skills are then passed on to communities, to ensure best practice but also ease of collaboration, using the same platforms - especially important given the globally distributed nature of Chicas Poderosas' communities.

The means of digital media production and consumption has also improved participation and representation of unheard voices featured in alternative media. In this respect Disha Mullick explains that "because of digital platforms, there's been a boom in non-mainstream independent news platforms producing different kinds of news in different voices in different languages for different audiences." She cites low production costs helping with this, allowing, in the case of Khabar Lahariya, the training of an "all women team that does the reporting" to produce the content in, about, and for their rural communities:

"I feel like digital journalism has the potential to make democracy a more lived and more relevant kind of reality, not just something that's theoretical, but that's actually accessible for women." (Disha Mullick)

This is noteworthy given some criticisms of mainstream local media journalists not being resident or of the areas they cover, and not understanding local issues adequately [13]. However, we have already established concerns about determinist views of technology. As we will see in the following section, technology can paradoxically contribute to some of the barriers to alternative media - and ultimately, we will close by seeing how it is the innovative and creative use of technologies that makes them powerful and effective in tackling these barriers.

\section{Barriers to alternative media practice}

One issue at the heart of post-2011 media development projects such as Check was how to determine the credibility (malicious or otherwise) of an upsurge in online media content. In being 'open' to a wide audience and user base, digital and social media comes with its own issues. Tom Trewinnard told us how problems were evident post-2011 when sources were simply assumed by journalists to be credible, partly due to pressures we can recognise as global, to maintain a continuing flow of news. Countering such issues therefore formed the initial basis for the Check work, starting in 2013. However, as well as requiring support and training in the direct, practical skills of journalism, scholars also recognise alternative media organisations are faced with other barriers, such as: the lack of opportunities and resources for improved journalism; the malicious use of media by regimes (Marwick and Lewis, 2017; Gunitsky, 2015; Elagati, 2013; Kausch, 2013), with blogging sometimes criminalised as 'fake news' (Michaelson, 2018); and the effect this has on hampering democracy and human rights improvements (Coulson, 2013). Here we explore such concerns as experienced by organisations operating in such challenging environments.

State control of alternative media is still a stark reality for some countries. Nora Younis, of the Al Manassa organisation in Egypt, drew perhaps the most sobering picture. She described alternative journalism as "shrinking [...] basically controlled by the state". For example, Al Manassa's coverage of what the government frames as a war against terrorism in Sinai, is controlled by "a law that says that the media can only publish official statements, published by them, by the army". She described how the state buys up and merges media outlets (television, Web sites, newspapers) (see also Issawi, 2020), or assigns their representatives to the board of independent, privately-owned media organizations to ensure some form of control. In cases where the state was unable to buy outlets or assign board members, Younis told us they instead simply blocked access for audiences, amounting to 500 blocked Web sites: "Basically, they don't want anyone on the scene that they cannot control." This claim is supported by Boserup, et al. [14], counting "blocking of up to 400 websites prior to the presidential elections in 2018". Al Manassa have experienced this control first hand. As well as their Web site being routinely 
blocked, their offices were raided in 2020 by the "copyright police" (Younis' phrase) for operating a laptop with the Linux operating system installed, but without a license from the Ministry of Communications and Information Technology. The charge was completely unexpected, especially given that Linux is open-source software, and it is thought this is the first time the 'cybercrime' law has been applied. Another issue for Younis was that anonymity was essentially being refused by the state. She described the process of having to apply for permission and give the Higher Council the full name of anyone wishing to post anonymously, which, in her mind, flies in the face of professional journalistic standards and their ability to report properly and safely: "So, as a journalist, you have to follow the law or be professional." The reality for Al Manassa is that they frequently take on freelance journalists anonymously, and the organisation takes on the considerable risk of protecting their identity. The situation in Egypt may be an extreme, but demonstrates the kind of pressures alternative media can be put under.

Bureaucratic structures in some countries make it difficult for organisations to even be recognised as valid journalism. Lebanon-based media organisation The Public Source made efforts to register as a non-government organisation (NGO). They attempted this in 2019 given that they weren't able to register as a media company, and were therefore not allowed membership of the journalist's syndicate and not recognised as journalists (Lara Bitar told us those types of licences hadn't been issued since the 1990s), and also wanted to avoid the paperwork and cost tied to registering as a civil company. However, their application for NGOstatus was rejected, with no reason given. The Public Source continue to operate illegally, in effect, with problems further exaggerated during the 2020 Covid19 pandemic lockdown:
"We were under partial or full lockdown for two to three months and journalists were technically allowed to be outside to do their work, but because we are not offically recognised as a media entity, our journalists had to find ways to manoeuver around the lockdown and hope they wouldn't get fined or face other consequences for breaking curfew." (Lara Bitar)

Nora Younis described similar bureaucratic hurdles to Al Manassa in Egypt, where all Web sites are required to apply for registration with the Supreme Council of Media. They applied for registration in October 2019 but had received no response as of August 2020, so continued to operate in "limbo [...] We don't have a license, but we're not rejected, you know, and they prefer to keep us this way and we don't know what to do." This is also likely to facilitate the state blocking of Al Manassa's Web site, given that they are, as Younis puts it, effectively "outlawed".

Tied into the bureaucratic pressures are the funding problems that many independent organisations face. The Public Source's difficulties in becoming registered meant they were unable to open bank accounts as an organisation and easily receive grants in order to maintain their independence, therefore relying on loopholes and workarounds to do so. This is problematic given that funding is often required at the outset. In Egypt, Nora Younis told us that applying for a licence costs $£ 50,000$, with penalties imposed for those practicing journalism without one: "the average is 300,000 pounds for publishing something [...] this can basically break any independent organization".

Many governments also perceive specific problems with receiving foreign funds. Pressures on civil society organizations (Teti and Gervasio, 2016) were present in the early years of the Check work (as evidenced from our reports), and partners were therefore reluctant to take disbursements, delaying project activities. In Egypt, regimes have criticised what they see as foreign intervention (El-Khalili, 2013), culminating in the prosecution of 43 workers from 17 different pro-democracy and rights groups in 2013 and the further targeting of more human rights and feminist researchers in 2016 (Abuzaid, 2019). Check's Egypt-based staff were therefore concerned at the atmosphere of hostility and possible legal risks associated with working on a project funded by a foreign government. Partners had training sessions cancelled, faced investigations from security forces, and were targeted by a media campaign aiming to stir mistrust and suspicion. Risks for Check partners and journalism trainees were therefore high. 
Such experiences still impact in Egypt today; Al Manassa do not take foreign funding on principle, because of the issues it creates, as many external funders consider Egypt unsafe for their program officers to visit their funded projects, and a portion of funds would be lost to Egypt's income and profit taxes rather than going to the recipient. Younis says there are therefore "less than five" safe external organisations to approach for funding. Given there is also little local funding for such initiatives, she defines Al Manassa in terms of 'surviving' rather than flourishing.

While distancing from foreign funds might seem to be the logical solution for such organisations then, other funding sources do not always easily present themselves. Belén Arce Terceros of Chicas Poderosas noted that much of their work is about engaging with underrepresented issues and vulnerabilities of the human rights of certain populations, which makes it hard to receive funding from government sources, or other companies and their interests. The Public Source also doesn't take funding that is "politically motivated, that comes with a specific agenda", due to similar concerns that it would compromise their position, and what they could do with it. In India, Disha Mullick reported there is funding available from "corporates" to cover politically supported issues such as development projects, sanitation or education, but not for anything politically sensitive, such as investigative work.

Tied into concerns about funding, is of course the issue of sustainability, how to maintain a level of activity. As both Lara Bitar and Nora Younis told us, funding is often available to start up projects, but it can be harder to communicate the need for ongoing support:

"Lots of donors will give you one-time support to launch your platform. But it's difficult to do long term strategic planning when you don't know if you're going to be able to survive next year. It's difficult to be able to expand and build on what's already been created and grow your team if you're not certain you can sustain yourself after the first year." (Lara Bitar)

"All the [funding] organizations don't want to be supporting a single media outlet forever. So they want you to somehow graduate and become sustainable and self sufficient." (Nora Younis)

Media organisations have obligations to their audiences, but also their staff and volunteers. Mariana Santos told us that Chicas Poderosas started as a voluntary project, which eventually grew to a full working team, but that this presents a continuous struggle to survive and meet those expectations: "We've grown to a point where there's no turning back, we can't go back to voluntary because we know how much is needed from us". Disha Mullick also points out the difficulty of trying to operate rural media under alternative structural and business models, where a mainstream approach would be to employ journalists as "stringers who are basically advertising agents". If Khabar Lahariya were to follow this, their work would then be affected as a result, in terms of staff resource but also subject matter, and this does not engender the kind of investigative journalism the organisation is supporting in those communities - therefore that finance model is not possible. Mullick also notes that the funding that is available does not largely support those at "the margins of knowledge production or media production", instead favouring those who are educated, skilled, English speaking and based in the cities. Meanwhile, the narrative from Egypt is that it is hard enough just to survive, let alone flourish or take the time to introspectively rethink organisational structure:

"There is no discussion about the profession itself. [...] In the past, it was not like that. There were always training sessions [...] there were always workshops, we would do debates about the profession, debates about how we should cover this or how we should cover that. But now there's no debate." (Nora Younis) 
Another issue is competition from other media. We have noted that mainstream media often draws attention through misinformation, clickbait and/or sensationalism in order to generate audiences, but in choosing not to fall in with dominant mainstream media tropes, it can be hard for alternative organisations to compete. Belén Arce Terceros said that in mainstream media:
"whatever someone says, it can become the main topic even if it's not the crucial issue at stake - polarised news that draws a lot of attention. Sometimes it's a struggle to keep relevant issues that aren't as attractive on the agenda." (Belén Arce Tercero)

On a technical level, Disha notes that covering marginal, under-reported issues is important but can also make their content hard to find:
"We have these challenges of [...] not being able to work these search engine optimisation guidelines, because we have content that just doesn't fall in those criteria. [...] And so then we work with marketing experts who say, 'Do the kind of news that you want to do, but also do 20 percent or 30 percent of the kind of news that you have to do to be able to be seen'." (Disha Mullick)

This therefore reinforces the suggestion that business savviness and an understanding of the wider field and competition this provides must be balanced against the core mission statement of each organisation.

Choosing to use digital media in such practices exposes the hold that global social media organisations have over everyday news media, as the payoff for their convenience of use. On a purely practical level, Check project reports sometimes noted that Facebook's grip on everyday audiences was such that it hindered project efforts to start new online spaces or tools. One of the partners commented that their users were initially "not excited" about using their new platform, and one journalist found it easier to update a story on the organisation's Facebook Group than on the Web site itself, with the organisation then supporting them in verification. Disha Mullick also said she was "uncomfortable" having to use platforms such as YouTube to reach audiences, saying that in rural areas at least, consumption had been "overtaken by the social media platforms". Creating their own platform to engage rural audiences was difficult given the competition from the likes of Facebook, Whatsapp and YouTube. Even when Khabar Lahariya's YouTube content then reached millions of viewers every month, the organisation found the financial advertising return to be low compared to other platforms, especially given that it also meant their content is 'owned' by YouTube as part of the terms of using the platform. Projects seeking to create new participatory but manageable audience spaces would therefore do well to understand the appeal of platforms such as Facebook, in attempting to draw audiences away from them.

Expanding on the earlier discussion about the operational aspects of media organisations, another issue is about the lack of certain staff and skills - beyond what we might think of 'journalism' - which are required to effectively run them. Disha Mullick's estimation was that "maybe 40 percent of [their] entire effort is the actual production of hyperlocal news but 60 percent of it is supporting the team", with the difficulty that marginalized, rural communities in India are not able to access the kind of knowledge and skills required. Given the variety of the organisations, they may be offering education, training, public engagement and technology development, as well as all the organisation of such activities. For example, Lara Bitar told us she was seeking a lawyer to support The Public Source's work in informing people about a new whistleblowing platform. These skills are sometimes developed over time, she says, but not always. It is perhaps not surprising then that Mariana Santos noted that even when projects are funded, problems arise: 
necessarily have the time and funding to support the operational and administrative side of journalism. We don't have the team, the assets [...] They are sometimes able to do the journalism, but not those other things." (Mariana Santos)

It is clear then, that alternative media organisations face challenges due to the oppositional nature of how they carry out their journalism and apply media production skills, but also due to their very existence (as non-mainstream) and independence. Whilst pressures from the state and other agencies might suggest they are therefore effective in being oppositional, it is clear they require support from projects such as Check Global. We will close this article by exploring how interventions might be useful to mitigate some of the barriers described above.

\section{Dealing with the barriers: How could development projects help?}

Many alternative media organisations start out by actively seeking to challenge and restructure what they see as the problematic notion of the mainstream media 'newsroom'. Chicas Poderosas operate professionally as a business, but balance this with avoiding tropes of mainstream media, such as sensationalist journalism which polarises for the sake of grabbing attention (Mourão and Robertson, 2019):
"One thing we've tried to do is break all these systems that don't work for women, collaboration, inclusion [...] to change the system of competitive journalism within a newsroom. Less about egos, more about working in a collaborative spirit." (Mariana Santos)

The organisational structure employed at The Public Source is non-hierarchical, which Lara Bitar sees as "core to [their]vision of setting a model for local independent journalism"; after an initial three months, each new individual becomes a member of the collective, with equal decisionmaking powers over editorial policies and funding allocation.

For Chicas Poderosas (operating across Latin America), "the problem is the lack of representation of women in leadership in media" (Santos), resulting in media output with limited gender perspectives, therefore also limiting the stories told and communities served. The organisation frames their work as a "movement" that resists traditional systems and structures (such as the idea of the 'newsroom'), through local, national, and international partnerships:

"Our main goal is to start conversations about these topics, focusing on the stories but also the people who are becoming better journalists and collaborators, part of media teams." (Mariana Santos)

In this re-arrangement of structures, there is also a recognition that this takes work, beyond any determinist view of technology as simply enabling alternative media production, as we've noted. As Mullick puts it:
"you can give a woman a computer and you're not actually shifting a political kind of structure that she operates within. And even though there are more opportunities for the democratization of media, that doesn't necessarily mean that the structures in which that media is located are changing on their own. That takes a lot of kind of simultaneous effort." (Disha Mullick)

This therefore, is the space that development projects such as Check Global must operate in, enabling and supporting independent media to establish and sustain themselves effectively, in order to ultimately result in improved digital literacy and journalism for their communities. One 
key factor of such development efforts is the extent to which we understand and take into account local nuance and differences. An organisation's partnership and networking with global peers is perhaps one of the aspects of Check Global that helps throw these differences into relief, as all our interviewees stressed that beyond funding, networking was important to their organisations and gave them a "very global overview of the problems from different perspectives" (Mariana Santos).

The Check work started in 2013 with one programmatic matrix for all countries of focus and unified training quantitative targets. However this shifted with the realisation that Egypt-based partners could easily bring together over 100 participants at each of their training sessions, but those in Syria were struggling to reach their targets for a number of reasons, most notably the fact that they were predominantly operating in rural areas with tightened security controls. Therefore, they intended to keep their sessions more targeted and localised, to avoid too much attention from the authorities. At the time of writing, our Egyptian interviewee reported pressures from the state; in Lebanon, power and Internet cuts, as well as the country's deepening economic crisis, notably in the aftermaths of the huge explosion which rocked Beirut port in August 2020, were all part of the problem. Even when a pandemic affects numerous countries, as in the 2020 Covid19 situation, the challenges are myriad. As such, a major learning outcome of the Check work has been in understanding the need to tailor objectives, inputs, processes and outputs to each of the contexts the project operated in. We have heard that sustainability is an issue, in finding funders who can support beyond an initial organisation setup, and this again makes the case for projects such as Check, with longer funding cycles - three years in this case.

Moreover, development projects like Check Global provide invaluable training for organisations, and their own training beneficiaries, especially in light of Nora Younis' comments that training and development have taken a back seat to their Al Manassa's mere survival. Check project work has created safe online and off-line spaces to carry out training. The project has also sought to help partners better use digital platforms, while negotiating the hold of those platforms on their work, given that the role of global social media platforms in these narratives of alternative media production can be significant. Whilst we have noted that technologies such as digital media don't in themselves result in quality journalism by their mere existence, in this article we have explored their creative use and affordances of accessibility for both practitioners and audiences. Therefore, training journalists in such practices is clearly valuable to individuals, media organisations and society.

Another issue in providing alternative, verified news streams, is in reaching audiences effectively; organisations must be prepared to find creative solutions. During the Check project work, when the Internet was blocked or Web sites shut down by authorities, Facebook was still sometimes able to provide a platform for the project partners. To some extent this supports narratives of social media's role in protest and civic movements (Mendes, et al., 2018; CostanzaChock, 2012). Facebook, for all its problems of corporate and commercial interests, data management and privacy (Fuchs, 2012), allows for engagement of both local and global audiences. However, within this narrative, it is worth noting how (drawing from Check project reports) authorities in partner countries sometimes responded on Facebook, applying social media as their own "tool of regime durability", disseminating malicious mis- and disinformation [15]. There seems to be a certain irony, that: 1) the state recognised Facebook was being seen as a place of free expression, one of the few places partners could safely reach large audiences given that their Web site was blocked; 2) the state did not necessarily directly challenge that free expression but co-opted it to send out their own messages, and surveil people. In this respect, both 'sides' were finding their audiences on Facebook, whether reluctantly or more actively appreciating the mass appeal of the platform. This of course results in a confusing battleground of information for the average user.

We acknowledge the important role of technology in the practice of alternative media, especially in enabling creative ways of adapting to shutdowns, attracting sources, or reaching new audiences, as we have discussed. However, use of technologies can sometimes create new concerns as we allow them space in our lives, and so an approach that demonstrates awareness and sensitivity is advised, akin to Ataman and Çoban's (2018) defensive activist tactics described 
earlier. Some organisations have to operate without registration, essentially illegally and, in addition to the various pressures applied by the state, it is perhaps unsurprising that Lara Bitar reported feeling unsafe online, with concerns about how her own mobile phone might be covertly used as a tool of surveillance; she only holds sensitive conversations face-to-face. Disha Mullick also discussed security concerns in the Khabar Lahariya rural media context, more directly aimed at their journalists and spilling into their everyday lives:

\begin{abstract}
"It's often likely that we'll do a story that rubs up against people in power in that district. And our journalists will be traveling in the same bus as a lot of the people who are trolling, and sending threats to them over WhatsApp.” (Disha Mullick)
\end{abstract}

Some of these trust issues and concerns can be mitigated with savvy use of technology. During the Check project work, 'safe' online spaces were set up for partners to undertake the training and carry out new investigative works. This sometimes meant integrating existing digital security resources such as Tactical Tech's 'security-in-a-box' [16] guide into the project activities, but also financially supporting external online hosting opportunities for partners. The NAWA Media Web site (North Africa Western Asia) was developed during the project as a platform for a group of Lebanon-based students and partners based in Syria and Yemen, who didn't necessarily have the proficiency to develop their own Web sites, to use and present their work in English and Arabic. By hosting on partner servers in the U.K., and being managed by the research team, this platform enabled Check partners to focus on writing their investigative stories and developing their journalism practice without fearing blocks or takedowns (as per Bitar's experiences). Lebanese journalism students who were involved as Check trainees suggested a certain isolation in work placements during their university studies; online spaces such as the Check verification platform and the project's NAWA Media Web site can be seen as key in sharing practice or working collaboratively in the face of the pressures we have described.

However, we must also recognise the precarious nature of the digital ecosystem itself (Hoskins, 2016; Chun, 2011). Many organisations therefore set up safe, off-line spaces, for people with no proper access to the Internet or who are facing digital security threats, to meet and collaborate. Some of the Check project's work had this focus, and our Khabar Lahariya and Chicas Poderosas interviewees also carried out off-line training sessions and workshops, and said participants really valued those opportunities to be with and collaborate with peers. In contrast, their value can also be demonstrated in Nora Younis' disappointment that she is now largely unable to run or participate in such events. It is worth noting how this echoes Aouragh and Alexander's (2011) work on the 2011 uprisings, suggesting that most of the activist organizing actually takes place off-line. Chicas Poderosas also stressed the value of using digital means to continue and extend the relationships that start with those off-line events, which was especially important during the 2020 Covid19 lockdowns, e.g., online workshops, Zoom video chat and a Facebook Group being used for an online course, including a jobs board - in an ideal world, off-line and online are relational.

Sometimes organisations also find workarounds and 'parallel' off-line ways of engaging with authorities and information that should be made public:

\footnotetext{
"In Lebanon very little is digitized so we understood very early on that if we wanted to reach the types of people who possibly have access to classified or sensitive information and are motivated to serve the public interest, that we would have to reach them a different way." (Lara Bitar)
}

The Public Source approach this with "guerilla marketing campaign on the street", explaining where and how to find relevant online information, and also encouraged people to contribute to it safely - "an informational campaign of sorts." 
Khabar Lahariya also recognise the importance of being visibly 'off-line' in a rural community, as their reporters work and run investigations there: "We haven't become a remote kind of newsroom that's distanced from the hyperlocal context which it was born in, and which created a really loyal audience and credibility" (Disha Mullick). The brand therefore has remained intact in the shift from print newspaper to digital, still recognised by the audience and local administration politicians.

\section{Conclusion}

The focus of this article has been to draw on current everyday narratives of global alternative media, and those of the Check project 2013-2020, to start a more honest discussion about barriers, needs and how these are met by digital technologies. We recognise the limitations of the interviews we undertook, but they have allowed us a rare depth and breadth of insight into four regions with differing challenges. The interviews were not intended to be exhaustive but to illustrate and provoke further discussion for both academics working in this field, but also funders and those wishing to support alternative and independent media in these contexts. Additional work in this area might involve more extensive surveys of practitioners and organisations, or ethnographic work to demonstrate the everyday challenges faced by such organisations.

Our interviewees, and the work of the Check project, demonstrate that journalism is in need of development in many global contexts, as well as the NAWA region. It is perhaps telling that our interviewees did not even focus on the details of how they carry out their investigative work, or training programmes; before even achieving this, many of these organisations are struggling to set up working practices or redesign the structure of the modern newsroom to better support marginal communities and groups, e.g., women in media leadership and media production.

Funders would do well to take note that many of these organisations find it hard to find appropriate funding sources that don't enforce agendas and draw funding that helps ongoing sustainability beyond initial setup costs. Our interviewees told us that their expectations and desire to carry out quality investigative journalism hold fast, as per Mulgan (2003) or McNair's ideals (2009) - as opposed to pandering to sensationalism, clickbait or finance-driven models. However, issues such as bureaucracy, specific blocks and appropriate funding sources make this difficult to achieve.

Finally, the interviewees and the experiences of the Check project present a complicated relationship between alternative media and the digital technologies they use. We have heard how global social media platforms do allow organisations to reach much wider audiences, and their 'offshore' locations are likely to make them harder to block than Web sites, e.g., in the case of Al Manassa. Their relative ease also means that new voices and communities can be trained in their use and represented online, with the support of organisations like Chicas Poderosas and Khabar Lahariya. However, use of digital technologies come with their own concerns and as fragility is exposed through shutdowns, blocks and privacy concerns, journalists and activists also see the value of being present off-line, whether in running workshops and networking events, or streetside awareness campaigns.

How can journalism be supported better in such emerging economies then? This article proposes a discussion but we would suggest that funders and development project leaders should start with direct consultation with potential partners and beneficiaries to design interventions and education specifically suited to their context. On the evidence of our interviews with leaders in their field, and drawing from experiences of the Check project, numerous issues and barriers have been presented, and it is perhaps no surprise that alternative streams of journalism in the NAWA and Global South regions have not been developed more effectively to date, nor that mainstream media in itself has not improved in its willingness to take such voices into account. However, we 
suggest that these scenarios should provide a challenge and motivation for those organisations wishing to support the development of journalism in these regions. Fm

\begin{abstract}
About the authors
Dr. Jerome Turner is a lecturer at the Birmingham Institute of Media and English, Birmingham City University. He has specific research interests in online hyperlocal journalism, community media and digital culture.

E-mail: jerome [dot] turner [at] bcu [dot] ac [dot] uk

Dr. Dima Saber is a Reader in Media \& Cultural Studies and Associate Director for External Funding and Research Development at the Birmingham Centre for Media and Cultural Research. Her research is focused on media depictions of conflict in the Arab region, and she is responsible for leading and delivering projects in citizen journalism in the Middle East and North Africa region, exploring ways digital literacy can foster social change and enhance the work of political activists in post-revolution and in conflict countries such as Lebanon, Syria, Yemen, Egypt and Palestine.

E-mail: dima [dot] saber [at] bcu [dot] ac [dot] uk
\end{abstract}

\title{
Acknowledgments
}

The authors recognize the contribution of E. Charlotte Stevens, who was part of the project team during the early stages of the Check project.

\section{Notes}

1. Mattoni and Treré, 2014, p. 98.

2. Meedan, at https://meedan.com/projects/check-global/, accessed 16 September 2020.

3. Ibid.

4. M. Safi, 2019. "Tunisia's presidential election to put young democracy to the test," Guardian (9 September), at https://www.theguardian.com/world/2019/sep/09/tunisia-presidential-electionwill-be-test-of-fledgling-democracy, accessed 14 September 2020.

5. Al-Shami, 2019, p. 2.

6. The Public Source, at https://thepublicsource.org/, accessed 14 September 2020. Bitar refers to herself as an "independent media worker" in her Twitter profile.

7. Khabar Lahariya, at https://khabarlahariya.org/, accessed 14 September 2020.

8. Al-Manassa, at https://almanassa.com/en, accessed 14 September 2020.

9. Meedan, at https://meedan.com/blog/check-global-strategy-in-latin-america/, accessed 14

September 2020.

10. Chicas Poderosas, at https://chicaspoderosas.org/, accessed 14 September 2020.

11. Mulgan, 2003, p. 66.

12. Ataman and Çoban, 2018, p. 1,014. 
13. Baines, 2012, p. 4.

14. Boserup, et al., 2019, p. 6.

15. Gunitsky, 2015, p. 42.

16. Security in-a-box is an online toolkit of resources created in 2009 , by Tactical Tech and Front Line Defenders, to meet the digital security and privacy needs of human rights defenders https://archive2015.tacticaltech.org/node/237.html, accessed 16 September 2020.

\section{References}

R.A. Abuzaid, 2019. “'Foreign funding' case nn. 173/2011: The implications of state encroachment on the feminist community in Egypt," Journal of Middle East Women's Studies, volume 15 , number 2 , pp. 237-243. doi: https://doi.org/10.1215/15525864-7491157, accessed 12 January 2021.

A. Al-Shami, 2019. "Unveiling of matters: The role of investigative journalism in uncovering corruption in the Arab world," IntechOpen, at https://www.intechopen.com/books/off-andonline-journalism-and-corruption-international-comparative-analysis/unveiling-of-matters-therole-of-investigative-journalism-in-uncovering-corruption-in-the-arab-world, accessed 14 September 2020.

doi: https://doi.org/10.5772/intechopen.86418, accessed 12 January 2021.

M. Aouragh and A. Alexander, 2011. "The Egyptian experience: Sense and nonsense of the Internet revolution," International Journal of Communication, volume 5, at https://ijoc.org/index.php/ijoc/article/view/1191, accessed 12 January 2021.

B. Ataman and P. Çoban, 2018. "Counter-surveillance and alternative new media in Turkey," Information, Communication \& Society, volume 21, number 7, pp. 1,014-1,029.

doi: https://doi.org/10.1080/1369118X.2018.1451908, accessed 12 January 2021.

C. Atton, 2002. Alternative media. London: Sage. doi: http://dx.doi.org/10.4135/9781446220153, accessed 12 January 2021.

D. Baines, 2012. "Hyper-local news: A glue to hold rural communities together?" Local Economy, volume 27, number 2, pp. 152-166. doi: https://doi.org/10.1177/0269094211428860, accessed 12 January 2021.

J. Bennett, 2014. "Introduction: the utopia of independent media: Independence, working with freedom and working for free," In: N. Strange and J. Bennett (editors). Media independence: Working with freedom or working for free? London: Routledge, pp. 15-42. doi: https://doi.org/10.4324/9781315776392, accessed 12 January 2021.

H. Bennis, R. Boustany, A.L. Dalena, H.J. Gentil, Y.J. Hajar, H. Sharif, S. Sharif, M. Welander and M. Zucconi, 2018. "Human rights and democracy in the Arab World in 2017: Hopeless within, doomed abroad," Global Campus Human Rights Journal, volume 2, pp. 96-126. doi: https://doi.org/20.500.11825/685, accessed 12 January 2021.

J. Bessant, 2014. Democracy bytes: New media, new politics and generational change. London: Palgrave Macmillan.

R.A. Boserup, E. Woertz, H. Hassan, E. Nagyn Rózsa and L. Zaccara, 2019. "Restoration, transformation and adaptation: Authoritarianism after 2011 in Egypt, Saudi Arabia and Iran," MENARA Working Papers, number 30, at https://www.iai.it/en/pubblicazioni/restorationtransformation-and-adaptation-authoritarianism-after-2011-egypt-saudi, accessed 12 January 2021. 
W.H.K. Chun, 2011. Programmed visions: Software and memory. Cambridge, Mass.: MIT Press.

S. Costanza-Chock, 2012. "Mic check! Media cultures and the Occupy movement," Social Movement Studies, volume 11, numbers 3-4, pp. 375-385.

doi: https://doi.org/10.1080/14742837.2012.710746, accessed 12 January 2021.

D.C. Coulson, 2013. "Dynamics of social media, politics and public policy in the Arab World," Global Media Journal, at https://www.globalmediajournal.com/open-access/dynamics-of-socialmedia-politics-and-public-policy-in-the-arab-world.pdf, accessed 12 January 2021.

M. Elagati, 2013. "Foreign funding in Egypt after the Revolution," FRIDE, at https://www.files.ethz.ch/isn/162759/WP EGYPT.pdf, accessed 14 September 2020.

S. El-Khalili, 2013. "Social media as a government propaganda tool in post-revolutionary Egypt," First Monday, volume 18, number 3, at https://firstmonday.org/article/view/4620/3423, accessed 14 September 2020.

doi: https://doi.org/10.5210/fm.v18i3.4620, accessed 12 January 2021.

M.H. Elmasry, D.M. Basiony and S.F. Elkamel, 2014. "Egyptian journalistic professionalism in the context of revolution: Comparing survey results from before and after the January 25, 2011 uprising," International Journal of Communication, volume 8, and at https://ijoc.org/index.php/ijoc/article/view/2568, accessed 12 January 2021.

M. El-Nawawy and S. Khamis, 2014. "Blogging against violations of human rights in Egypt: An analysis of five political blogs," International Journal of Communication, volume 8, pp. 962 982, and at https://ijoc.org/index.php/ijoc/article/view/2043, accessed 12 January 2021.

M. Elswah and P.N. Howard, 2020. "The challenges of monitoring social media in the Arab world: The case of the 2019 Tunisian elections," Oxford Project on Computational Propaganda, Data Memo, number 2020.1, at https://www.oii.ox.ac.uk/research/projects/computationalpropagandal, accessed 12 January 2021.

K.V.L. England, 1994. "Getting personal: Reflexivity, positionality, and feminist research,” Professional Geographer, volume 46, number 1, pp. 80-89.

doi: https://doi.org/10.1111/j.0033-0124.1994.00080.x, accessed 12 January 2021.

C. Fuchs, 2012. "The political economy of privacy on Facebook," Television \& New Media, volume 13, number 2, pp. 139-159.

doi: https://doi.org/10.1177/1527476411415699, accessed 12 January 2021.

A.R. Gallardo, F.M. Burkle, L. Ragazzoni and F. Della Corte, 2016. "Yemen's unprecedented humanitarian crisis: Implications for international humanitarian law, the Geneva Convention, and the future of global health security," Disaster Medicine and Public Health Preparedness, volume 10 , number 5, pp. 701-703.

doi: https://doi.org/10.1017/dmp.2016.50, accessed 12 January 2021.

S. Gunitsky, 2015. "Corrupting the cyber-commons: Social media as a tool of autocratic stability," Perspectives on Politics, volume 13, number 1, pp. 42-54.

doi: https://doi.org/10.1017/S1537592714003120, accessed 12 January 2021.

Z. Harb, 2019. "Challenges facing Arab journalism, freedom, safety and economic security," Journalism, volume 20, number 1, pp. 110-113.

doi: https://doi.org/10.1177/1464884918807356, accessed 12 January 2021.

M. Hirst, 2012. "One tweet does not a revolution make: Technological determinism, media and social change," Global Media Journal, volume 6, number 2, pp. 1-11.

A. Hoskins, 2016. "Archive me! Media, memory, uncertainty" In: A. Hajek, C. Lohmeier and C. Pentzold (editors). Memory in a mediated world: Remembrance and reconstruction. London: 
Palgrave Macmillan, pp. 13-35.

doi: https://doi.org/10.1057/9781137470126 2, accessed 12 January 2021.

Human Rights Watch, 2019. "Egypt: Events of 2018," at https://www.hrw.org/worldreport/2019/country-chapters/egypt, accessed 14 September 2020.

F. el Issawi, 2020. "Egyptian journalists and the struggle for change following the 2011 uprising: The ambiguous journalistic agency between change and conformity," International

Communication Gazette, volume 2, number 7, pp. 628-645.

doi: https://doi.org/10.1177/1748048519897516, accessed 12 January 2021.

K. Kausch, 2013. "“Foreign funding' in post-revolution Tunisia," FRIDE, at https://www.files.ethz.ch/isn/167265/WP Tunisia.pdf, accessed 14 September 2020.

A. Marwick and R. Lewis, 2017. "Media manipulation and disinformation online," Data \& Society (15 May), at https://datasociety.net/library/media-manipulation-and-disinfo-online/, accessed 14 September 2020.

A. Mattoni and E. Treré, 2014. "Media practices, mediation processes, and mediatization in the study of social movements," Communication Theory, volume 24, number 3, pp. 252-271. doi: https://doi.org/10.1111/comt.12038, accessed 12 January 2021.

B. McNair, 2009. “Journalism and democracy,” In: K. Wahl-Jorgensen and T. Hanitzsch (editors). Handbook of Journalism Studies. London: Routledge, pp. 237-249.

K. Mendes, J. Ringrose and J. Keller, 2018. "\#MeToo and the promise and pitfalls of challenging rape culture through digital feminist activism," European Journal of Women's Studies, volume 25, number 2, pp. 236-246.

doi: https://doi.org/10.1177/1350506818765318, accessed 12 January 2021.

R. Michaelson, 2018. “Fake news' becomes tool of repression after Egypt passes new law," Guardian (27 July), at https://www.theguardian.com/global-development/2018/jul/27/fake-newsbecomes-tool-of-repression-after-egypt-passes-new-law, accessed 18 November 2018.

R.R. Mourão and C.T. Robertson, 2019. "Fake news as discursive integration: An analysis of sites that publish false, misleading, hyperpartisan and sensational information," Journalism Studies, volume 20, number 14, pp. 2,077-2,095.

doi: https://doi.org/10.1080/1461670X.2019.1566871, accessed 12 January 2021.

R. Mourtada and F. Salem, 2014. "Citizen engagement and public services in the Arab world: The potential of social media," Arab Social Media Report, Sixth edition, at hhttps://www.mbrsg.ae/getattachment/e9ea2ac8-13dd-4cd7-9104-b8f1f405cab3/CitizenEngagement-and-Public-Services-in-the-Arab.asp $\underline{x}$, accessed 12 January 2021.

R. Mulgan, 2003. Holding power to account: Accountability in modern democracies. London: Palgrave Macmillan. doi: https://doi.org/10.1057/9781403943835, accessed 12 January 2021.

J. Post and V. Crone, 2015. "Reporting revolution: Technological determinism in journalistic reports on social media and movements," Digital Journalism, volume 3, number 6, pp. 871-887. doi: https://doi.org/10.1080/21670811.2014.990253, accessed 12 January 2021.

M. Robbins, 2015. "After the Arab Spring: People still want democracy," Journal of Democracy, volume 26, number 4, pp. 80-89, and at https://www.journalofdemocracy.org/articles/after-thearab-spring-people-still-want-democracy $\underline{\underline{\prime}}$, accessed 12 January 2021.

A. Russell, 2016. Journalism as activism: Recoding media power. Cambridge: Polity Press. 
M. Safi, 2019. “Tunisia's presidential election to put young democracy to the test," Guardian (9 September), at https://www.theguardian.com/world/2019/sep/09/tunisia-presidential-electionwill-be-test-of-fledgling-democracy, accessed 14 September 2020.

Syrian Observatory For Human Rights, 2018. “About 522 thousand people were killed in 90 months since the start of the Syrian revolution in March 2011" (13 September), at https://www.syriahr.com/en/102385/, accessed 14 September 2020.

A. Teti and G. Gervasio, 2012. "After Mubarak, before transition: The challenges for Egypt's democratic opposition," Interface, volume 4, number 1, pp. 102-112.

B. Warf, 2011. "Myths, realities, and lessons of the Arab Spring," Arab World Geographer, volume 14, number 2, pp. 166-168.

doi: https://doi.org/10.5555/arwg.14.2.kn2t487953h8w161, accessed 12 January 2021.

\section{Editorial history}

Received 10 July 2019; revised 10 October 2020; accepted 8 January 2021.

\footnotetext{
"Understanding factors and barriers to alternative media development in emerging economies: Learning from the Check Global project" by Jerome Turner and Dima Saber is licensed under a Creative Commons Attribution-NonCommercial-NoDerivatives 4.0 International License.
}

Understanding factors and barriers to alternative media development in emerging economies: Learning from the Check Global project by Jerome Turner and Dima Saber.

First Monday, Volume 26, Number 2 - 1 February 2021 https://journals.uic.edu/ojs/index.php/fm/article/download/11370/10066 doi: https://dx.doi.org/10.5210/fm.v26i2.11370 